\title{
Pengaruh lama perebusan terhadap daya hambat radikal bebas, viskositas dan sensori sirup secang (Caesalpinia sappan $L$.)
}

\author{
The effect of boiling time on against inhibition of free radicals, viscosity and sensory \\ sapanwood syrup (Caesalpinia Sappan L.)
}

\author{
Sarlina Palimbong ${ }^{1,2 *}$, Gelora Mangalik ${ }^{3)}$, Alifia Lila Mikasari ${ }^{3)}$ \\ ${ }^{1}$ Program Studi Teknologi Pangan, Fakultas Kedokteran dan Ilmu Kesehatan, \\ Universitas Kristen Satya Wacana \\ ${ }^{2}$ Pusat Studi Pangan Fungsional, Universitas Kristen Satya Wacana \\ ${ }^{3}$ Program Studi Ilmu Gizi, Fakultas Kedokteran dan Ilmu Kesehatan, Universitas \\ Kristen Satya Wacana \\ email*: sarlina.palimbong@uksw.edu \\ Informasi Artikel: \\ Dikirim: 29/11/2019; ditinjau: 30/11/2019; disetujui: 12/01/2020
}

\begin{abstract}
Sappanwood (Caesalpinia sappan L.) is a plant that can be used as traditional medicine to treat tuberculosis, diarrhea, dysentery, skin infections, anemia, and several other diseases. Sappanwood containing brazilin as main compound which has antioxidant properties. The main compound of sappanwood can be presented in the form of products such as syrup. Syrup is practical and makes it easy for consumers to get the functional properties of brazilin. The process of making syrup used boiling method. The purpose of this study was to see the effect of boiling time on the inhibition of free radicals, viscosity and sensory sappanwood syrup. Sappanwood extraction with maceration method using water. The making of sappadwood syrup used additional material cinnamon, lemongrass, ginger, and clove boiled with water and sugar until it thickens. Syrup boiling time is 60, 90, and 120 minutes at a temperature of $60-70^{\circ} \mathrm{C}$ with three replications. Then the syrup is tested for inhibition using the DPPH method, viscosity, and sensory. Data analysis techniques using Microsoft Excel software. The results showed that boiling time resulted in a decrease in inhibition of free radicals, where the initial inhibition was 56,644\% to 28,803\%, 22,776\% and 29,593\%. The viscosity of the sappanwood syrup increases with the length of boiling time. Based on sensory tests, the level of panelist preference is influenced by the length of boiling. Panelists prefer syrup that is boiled for 90 minutes for the parameters of taste, color and thickness while for the scent panelists like syrup that was boiled for 120 minutes
\end{abstract}

Keywords: brazilin, sappanwood, sensory, syrup, viscosity

\begin{abstract}
ABSTRAK
Secang (Caesalpinia sappan L.) merupakan tanaman dapat yang digunakan sebagai obat tradisional untuk mengobati TBC, diare, disentri, infeksi kulit, anemia, dan beberapa penyakit lainnya. Secang mengandung brazilin sebagai senyawa utamanya yang memiliki sifat antioksidan. Kandungan utama secang ini dapat dihadirkan dalam bentuk produk olahan seperti sirup. Sirup bersifat praktis dan memudahkan konsumen untuk mendapatkan sifat fungsional brazilin di dalamnya. Proses pembuatan sirup menggunakan metode perebusan. Tujuan penelitian ini adalah untuk melihat pengaruh lama perebusan terhadap daya hambat radikal bebas, viskositas dan sensori pada sirup secang. Ekstraksi secang dengan metode maserasi menggunakan air. Pembuatan sirup
\end{abstract}


secang menggunakan bahan tambahan kayu manis, serai, jahe, dan cengkih yang direbus dengan ditambahkan air dan gula hingga mengental. Lama perebusan sirup adalah 60, 90, dan 120 menit pada suhu $60-70^{\circ} \mathrm{C}$ dengan ulangan sebanyak tiga kali. Sirup secang kemudian diuji daya hambatnya menggunakan metode DPPH, viskositas, dan sensorinya. Teknik analisis data menggunakan software Microsoft Excel. Hasil penelitian menunjukkan lama perebusan menghasilkan penurunan daya hambat radikal bebas, di mana daya hambat semula $56,644 \%$ menjadi $28,803 \%, 22,776 \%$ dan $29,593 \%$. Viskositas sirup secang semakin meningkat seiring lamanya waktu perebusan. Berdasarkan uji sensori, tingkat kesukaan panelis dipengaruhi oleh lama perebusan. Panelis lebih menyukai sirup yang direbus selama 90 menit untuk parameter rasa, warna dan kekentalan sedangkan untuk aroma panelis menyukai sirup yang direbus selama 120 menit.

Kata Kunci: brazilin, secang, sensori, sirup, viskositas

\section{PENDAHULUAN}

Secang (Caesalpinia sappan L.) merupakan tanaman dari keluarga Leguminosae. Kayu secang banyak ditemukan di Asia Tenggara termasuk Indonesia dan banyak digunakan sebagai bahan makanan dan minuman tradisional (Toegel et al., 2012). Kayu secang biasanya digunakan sebagai pewarna merah alami sedangkan di Thailand, kayu secang digunakan sebagai obat tradisional untuk mengobati TBC, diare, disentri, infeksi kulit dan anemia. Secang mengandung senyawa fenol termasuk xanthone, kumarin, chalcones, flavonoid, dan brazilin (Nirmal et al., 2015). Brazilin merupakan senyawa utama yang terdapat pada secang. Di Cina, brazilin digunakan untuk pengobatan yang meningkatkan sirkulasi darah, memperlancar menstruasi, dan sebagai anti - inflamasi. Selain itu brazilin memiliki manfaat sebagai antibakteri, hipoglikemik, anti - alergi, dan anti oksidan (Nirmal et al., 2015). Tanaman obat biasanya disajikan dalam bentuk minuman kesehatan seperti jamu, sirup, jus dan minuman instan. Kayu secang merupakan salah satu tanaman obat yang digunakan sebagai bahan baku minuman fungsional (Miksusanti, Fitrya, dan Marfinda, 2011).

Menurut Badan Standar Nasional Indonesia-SNI nomor 3544:2013. (2013), sirup merupakan produk minuman yang terbuat dari campuran air dan gula dengan kadar larutan gula minimal 65\%. Sirup merupakan salah satu produk minuman yang praktis dan ekonomis. Dalam pembuatan sirup dapat ditambahkan bahan - bahan pangan yang diizinkan dan sesuai ketentuan berlaku seperti rempah - rempah yang dapat meningkatkan sifat fungsional sirup (Nasional, 2013). Rempah-rempah kaya akan senyawa bioaktif yang menyebabkan sifat fungsional tertentu sehingga menjadikan produk olahan pangan yang kaya rempah disebut dengan pangan fungsional. Pangan fungsional memberikan manfaat antara lain pencegahan penyakit degeneratif, peningkatan imunitas, perlambatan proses (Ishartani dan Khasanah, 2012). Bahan rempah - rempah lain seperti kayu manis, serai, jahe dan cengkih merupakan bahan yang dapat digunakan sebagai bahan tambahan dalam sirup secang. Kayu manis berbau wangi dan berasa manis sehingga dapat dijadikan bahan pembuat sirup dan rasa pedas sebagai penghangat tubuh (Emilda, 2018). Selain digunakan sebagai penambah cita rasa juga mengandung sinamaldehid, eugenol, asam sinamat, katekin, epikatekin, dan senyawa polifenol lain. Senyawa fitokimia ini menjadikan kayu manis potensial sebagai antioksidan (Hastuti dan Rustanti, 2014). Kayu manis memiliki kemampuan antimikroba, antifungi, antivirus, antioksidan, antitumor, penurun tekanan darah, kolesterol dan memiliki senyawa rendah lemak (Emilda, 2018). Serai (Cymbopogon citratus) merupakan salah satu tanaman obat yang memiliki kandungan flavonoid, polifenol, saponin dan minyak 
atsiri yang dapat berfungsi sebagai antioksidan (Hendrik, Erwin, dan Panggabean 2013). Jahe mengandung senyawa bioaktif golongan fenol, flavonoid terpenoid dan minyak atsiri yang berfungsi sebagai antimikroba dan antioksidan (Mursalim dan Jamaluddin, 2019). Kandungan eugenol pada cengkih sebagai antioksidan mempunyai potensi yang baik dalam pengobatan penyakit parkinson maupun penyakit cardiac hyperthripy (sejenis penyakit jantung) (Towaha, 2012). Bahan tambahan sirup secang selain rempah - rempah adalah gula pasir (sukrosa) yang berfungsi untuk memperbaiki sifat organoleptik terutama rasa. Bahan rempah rempah yang ditambahkan mempunyai sifat sebagai antioksidan (Ishartani dan Khasanah, 2012) yang dapat meningkatkan daya inhibisi serta meningkatkan sifat organoleptik rasa dan aroma pada sirup secang.

Pemanfaatan kayu secang digunakan sebagai obat tradisional dengan cara kayu secang direbus dengan air, kemudian meminum atau membalurkan air rebusannya pada bagian tubuh yang sakit. Pada umumnya lama waktu dan tinggi suhu perebusan tidak diperhatikan oleh masyarakat dalam pemanfaatan kayu secang dengan cara direbus. Kandungan suatu senyawa dapat dipengaruhi oleh lama waktu dan tinggi suhu perebusan. Dalam hal ini stabilitas senyawa brazilin dapat dipengaruhi oleh waktu yang terlalu lama dan suhu yang terlalu tinggi. Suhu optimal dalam pemanasan secang dengan menggunakan suhu $70^{\circ} \mathrm{C}$ (Farhana, Maulana, dan Kodir, 2015). Selain stabilitas senyawa, lama perebusan akan mempengaruhi viskositas, dan sensori suatu produk. Oleh karena itu penelitian ini ingin melihat pengaruh lama perebusan terhadap daya inhibisi senyawa brazilin, viskositas dan sensori pada sirup secang.

\section{METODE PELAKSANAAN}

\section{Waktu dan tempat}

Penelitian ini dilakukan pada bulan

Mei hingga Juli 2019. Penelitian ini dilaksanakan di Laboratorium food processing dan laboratorium biokimia Fakultas Kedokteran dan Ilmu Kesehatan, Universitas Kristen Satya Wacana, Salatiga. Analisis aktivitas antioksidan dilakukan di Laboratorium Kimia FSM, Universitas Kristen Satya Wacana, Salatiga.

\section{Bahan dan alat}

Bahan utama yang digunakan adalah kayu secang, kayu manis, serai, jahe, cengkih, air, dan gula. Bahan kimia yang digunakan adalah $200 \mathrm{ml}$ DPPH.

Alat yang digunakan adalah erlenmeyer, rotary (vaccum) evaporator, gelas piala, kertas saring, timbangan digital, gelas ukur, inkubator, Spektrofotometer UVVis, termometer, panci, kompor, botol kaca, spatula, viskometer.

\section{Cara ekstraksi secang}

Kayu secang 10 gr, kayu manis 1 ruas, serai 1 ruas, jahe 25 gr ,cengkih 1 buah, air $100 \mathrm{ml}$ dan gula 65 gr dimaserasi selama 48 jam (Putri, Mukharomah, dan Sulistyaningsih, 2018).

\section{Uji daya hambat}

Pengujian daya hambat menggunakan metode DPPH (2,2-difenil-1-pikrilhidrazil). Sampel sebanyak $10 \mathrm{mg} / \mathrm{mL}$ ditambahkan 1,5 mL DPPH 0,15 mM pada $95 \%$ etanol. Setelah inkubasi pada suhu kamar selama 30 menit di tempat yang gelap, kemudian serapan di ukur dengan spektofotometer $U V$ $V i s$ pada panjang gelombang $517 \mathrm{~nm}$. Persentase penghambatan radikal DPPH dihitung dari persamaan berikut

$$
\begin{aligned}
& \% \text { daya hambat radikal bebas }= \\
& \frac{\text { Rerata Abs Blanko-Rerata Abs sampel }}{\text { Rerata Abs Blanko }} \times 100 \%
\end{aligned}
$$

\section{Pembuatan sirup}

Pembuatan sirup menggunakan metode perebusan campuran air dan gula dengan kadar larutan gula minimal $65 \%$ dengan atau tanpa bahan pangan lain dan atau bahan tambahan pangan yang diizinkan sesuai ketentuan yang berlaku (Nasional, 2013). Bahan kering yang digunakan antara lain kayu secang 100 gr, kayu manis 1 batang, 
serai 5 batang, jahe 250 gr dan cengkih 7 buah. Bahan - bahan tersebut direbus dengan penambahan $1000 \mathrm{ml}$ air dan gula $650 \mathrm{gr}$ hingga mengental dengan waktu perebusan dilakukan dengan variasi waktu 60 menit, 90 menit, 120 menit.

\section{Uji viskositas}

Sebanyak $100 \mathrm{~mL}$ sampel diukur viskositasnya menggunakan viskometer. Viskometer dijalankan, kemudian nilai viskositas dari sirup akan terbaca (Sayuti dan Winarso, 2015).

\section{Uji sensori}

Penilaian organoleptik terhadap produk sirup secang yang meliputi warna, kekentalan, aroma dan rasa dengan menggunakan pengujian hedonik. Pengujian ini berdasarkan pada pemberian skor kesukaan panelis terhadap warna, kekentalan, aroma dan rasa. Pengujian ini menggunakan panelis sebanyak 40 orang (Mondo, Ansaharullah, dan Tamrin, 2017).

\section{Rancangan penelitian}

Penelitian ini dilakukan menggunakan metode eksperimental dengan perlakuan suhu $60-70^{\circ} \mathrm{C}$ dan lama perebusan selama 60 menit, 90 menit, dan 120 menit. Setiap perlakuan suhu diulangi sebanyak tiga kali.

\section{Analisa data}

Teknik pengolahan data dilakukan dengan membandingkan nilai persentase daya hambat radikal bebas ekstrak sampel sebelum dan sesudah diberi perlakuan lama perebusan, viskositas dan organoleptik menggunakan aplikasi Microsoft Excel. Hasil uji daya hambat menggunakan DPPH disajikan pada Tabel 1.

\section{HASIL DAN PEMBAHASAN}

Ketahanan terhadap panas wajib dipenuhi oleh senyawa antioksidan dalam suatu bahan pangan ketika akan diolah sebab proses pengolahan bahan pangan umumnya menggunakan suhu tinggi. Hasil uji daya hambat radikal bebas metode 1,1-difenil-2pikrilhidrazil (DPPH) disajikan pada Tabel 1.

\section{Persentase daya hambat radikal bebas pada ekstrak dan sirup secang}

Kemampuan penghambat radikal bebas sirup secang digambarkan pada tebel 1 di bawah ini

Tabel 1. Aktivitas antioksidan ekstrak dan sirup secang

\begin{tabular}{|c|c|c|c|c|c|}
\hline Sampel & Kondisi & $\begin{array}{r}\text { Waktu } \\
\text { (menit) }\end{array}$ & $\begin{array}{r}\text { Rerata Abs } \\
\text { blanko } \pm \text { SD }\end{array}$ & $\begin{array}{c}\text { Rerata Abs } \\
\text { sampel } \pm \text { SD }\end{array}$ & $\begin{array}{c}\% \text { Daya Hambat } \\
(\%) \pm \text { SD }\end{array}$ \\
\hline Ekstrak & $\begin{array}{l}\text { Sebelum } \\
\text { menjadi } \\
\text { sirup }\end{array}$ & 2880 & $0,725 \pm 0,000577$ & $0,314 \pm 0,024$ & $56,644 \pm 3,311$ \\
\hline 1 & Sesudah & 60 & & $0,571 \pm 0,0010$ & $28,803 \pm 0,124$ \\
\hline 2 & menjadi & 90 & $0,802 \pm 0,000577$ & $0,619 \pm 0,0005$ & $22,776 \pm 0,071$ \\
\hline 3 & sirup & 120 & & $0,565 \pm 0,0005$ & $29,593 \pm 0,071$ \\
\hline
\end{tabular}

*Sebelum dilakukan perebusan

**Setelah dilakukan perebusan

Berdasarkan Tabel 1 di atas dapat diketahui kemampuan penghambatan radikal bebas sirup secang sebelum diberikan pemanasan memiliki nilai sebesar 56,644\%. Kemampuan ini mengalami penurunan setelah sirup secang melalui proses perebusan selama 60 menit yaitu menghasilkan daya hambat $28,803 \%$. Setelah perebusan selama 90 menit menghasilkan daya hambat $22,776 \%$, dan sebanyak $29,593 \%$ setelah perebusan selama 120 menit. Semakin besar nilai persentase inhibisi sampel maka semakin tinggi aktivitas antioksidannya dan sebaliknya. Ketika radikal DPPH bereaksi dengan senyawa antioksidan melalui pengambilan ion hidrogen maka akan terjadi proses inhibisi (Susanto dan Setyohadi, 2011). Setelah melalui proses perebusan persentase penghambatan radikal bebas pada sirup secang mengalami penurunan sehingga ada kemungkinan aktivitas antioksidan sirup secang juga mengalami penurunan (Kusuma, Susilorini, dan Surjowardojo, 2017). 
Brazilin termasuk senyawa fenol. Umumnya semakin tinggi kandungan senyawa aktif di dalam ekstrak seperti senyawa fenol maka semakin tinggi aktivitas antioksidannya sehingga daya hambat radikal bebas semakin kuat (Dewi, Ulya dan Argo, 2017). Namun, apabila semakin lama terpapar panas akan sangat mempengaruhi kemampuan senyawa fenol dalam menangkap radikal bebas (Amperawati et al., 2019). Selama perebusan total fenol akan hilang melalui dua cara yaitu terlarut dalam cairan dan mengalami oksidasi. Selama perebusan secang berhubungan langsung dengan panas yang dihasilkan oleh air mendidih, sehingga dinding sel dan membran plasma cepat mengalami kerusakan. Dengan demikian, air perebusan masuk ke dalam dinding sel kemudian melarutkan senyawa fenol ke dalam cairan pengolahan. Fenol yang larut sebagian menguap ke udara bersama uap air. Kemudian cara fenol mengalami oksidasi disebabkan adanya aktivitas enzim polifenol oksidase yang membentuk radikal bebas yang bersifat reaktif akibat adanya panas dan oksigen (Aisyah, Rasdiansyah, dan Muhaimin, 2015),

\section{Uji viskositas}

Viskositas atau kekentalan adalah salah satu sifat zat cair yang berhubungan dengan hambatan untuk mengalir. Beberapa cairan dapat mengalir dengan cepat seperti minyak, madu, gliserin dan oli karena memiliki viskositas yang besar, sedangkan air memiliki viskositas yang lebih kecil sehingga dapat mengalir dengan cepat. Zat cair akan semakin sulit untuk mengalir apabila viskositas suatu cairan semakin besar begitu pula sebaliknya (Lubis, 2018).

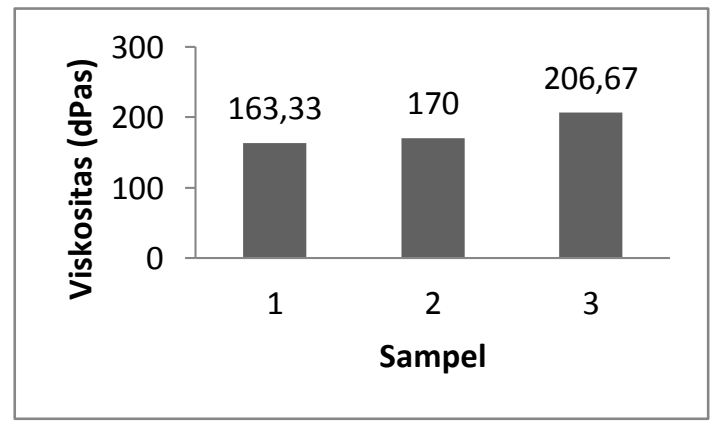

Gambar 1. Grafik rata - rata viskositas sirup secang
Berdasarkan gambar 1 di atas, dapat diketahui bahwa viskositas produk berbedabeda. Nilai rata - rata viskositas pada sampel sirup secang mengalami peningkatan di setiap perlakuan waktu. Hal ini dikarenakan lama perebusan dan gula yang ditambahkan akan mempengaruhi kekentalan zat cair. Sirup akan semakin kental apabila proses perebusan yang dilakukan semakin lama (Ananda, Yuwono dan Wijayanti, 2017). Air akan lebih banyak diikat oleh gula, sehingga viskositas meningkat. Penambahan gula selain digunakan sebagai pemanis juga dapat sebagai sumber padatan sehingga dapat meningkatkan viskositas sirup (Bastanta, Karo-Karo dan Rusmarilin, 2017). Namun, standar viskositas sirup belum ditetapkan oleh SNI.

\section{Uji organoleptik}

Penilaian organoleptik terhadap sirup secang meliputi rasa, aroma, warna dan kekentalan dengan menggunakan skala hedonik. Panelis akan memberikan skor terhadap rasa, aroma, warna dan kekentalan pada pengujian ini. Sebanyak 50 panelis tidak terlatih akan terlibat dalam pengujian organoleptik sirup secang. Skor penilaian yang digunakan 1 sampai 5 dengan kriteria penilaian 1 = sangat tidak suka, $2=$ tidak suka, $3=$ agak suka , $4=$ suka, $5=$ sangat suka (Radhiansyah, Ansharullah, dan Khaeruni, 2018).

\section{Rasa}

Rasa merupakan salah satu faktor dalam menentukan kualitas makanan. Rasa dapat dihasilkan oleh makanan yang masuk ke dalam mulut yang kemudian memengaruhi reaksi indera. Agar merangsang indera, makanan yang disajikan harus memiliki cita rasa yang baik sehingga menimbulkan selera makan yang baik pula (Tarwendah, 2017). Berdasarkan uji hedonik dapat diketahui bahwa tingkat kesukaan panelis terhadap rasa produk berbeda-beda. Sirup secang sampel kedua memiliki nilai skor kesukaan tertinggi, yaitu 3,09, sedangkan rasa yang paling tidak disukai adalah rasa sampel pertama dengan nilai kesukaan sebesar 2,98. 


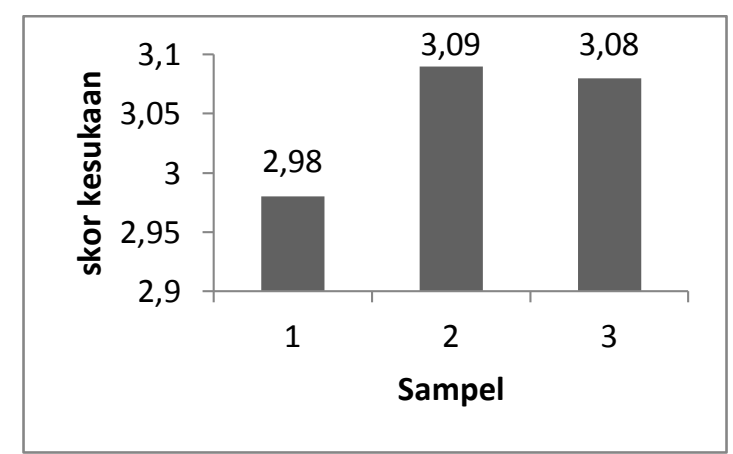

Gambar 2. Grafik rata - rata tingkat kesukaan rasa sirup secang

Berdasarkan gambar 2 di atas, tingkat kesukaan rasa menunjukkan sirup secang yang paling disukai adalah sirup secang sampel 2 dengan lama perebusan 90 menit. Pada pembuatan sirup secang salah satu bahan yang digunakan adalah jahe. Proses perebusan yang semakin lama menyebabkan gingerol yang terkandung dalam jahe yang sangat tidak stabil dengan panas akan berubah menjadi shogaol. Shogaol menciptakan rasa yang lebih pedas (Mardhatilah, 2015). Sehingga rasa yang ditimbulkan lebih pedas pada lama perebusan selama 120 menit. Selain itu semakin lama proses perebusan dapat menyebabkan daya larut dari gula semakin tinggi (Ananda, Yuwono dan Wijayanti 2017) rasa yang dihasilkan lebih manis dibandingkan sampel pertama dan kedua. Berdasarkan penilaian panelis sampel pertama dengan lama perebusan selama 60 menit rasa rempah rempah kurang terasa sehingga panelis tidak begitu menyukai sampel pertama dengan lama perebusan 60 menit dan sampel ketiga dengan lama perebusan 120 menit karena rasa sirup sangat manis dan meninggalkan after teaste pedas dari jahe.

\section{Aroma}

Aroma adalah bau yang ditimbulkan oleh rangsangan kimia yang tercium oleh syaraf-syaraf olfaktori yang berada dalam rongga hidung sehingga dapat meningkatkan selera (Negara et al., 2016). Berdasarkan uji hedonik dapat diketahui bahwa tingkat kesukaan panelis terhadap aroma produk berbeda-beda. Sirup secang sampel ketiga memiliki nilai skor kesukaan tertinggi, yaitu 3,25 , sedangkan rasa yang paling tidak disukai adalah rasa sampel pertama dengan nilai kesukaan sebesar 2,89.

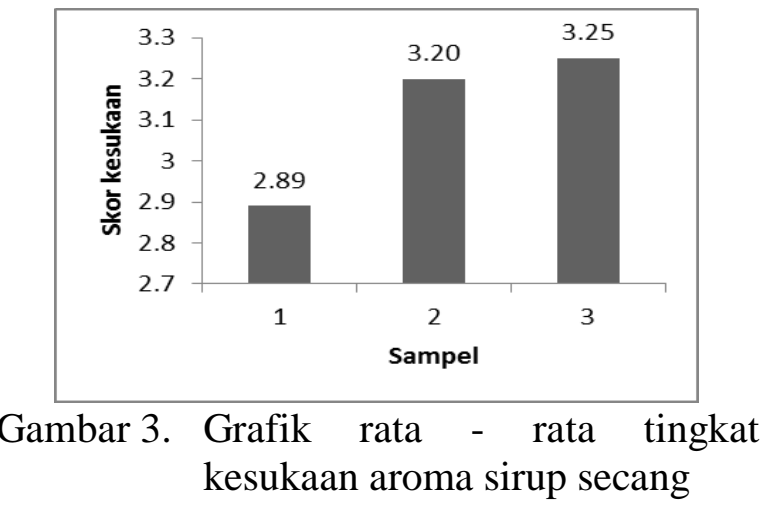

Berdasarkan gambar 3 di atas, tingkat kesukaan aroma menunjukkan sirup secang yang paling disukai adalah sirup secang dengan sampel ketiga. Berdasarkan penilaian panelis sampel ketiga dengan lama perebusan selama 120 menit memiliki perpaduan aroma rempah - rempah yang kuat, aroma yang dihasilkan adalah aroma khas rempah rempah (jahe, kayu manis, serai, dan cengkih). Semakin lama pemanasan maka semakin tinggi nilai organoleptik aroma, hal tersebut disebabkan aroma rempah - rempah akan semakin kuat. Rimpang jahe mengandung minyak atsiri yang menimbulkan aroma khas (Mardhatilah, 2015). Senyawa sinamaldehid dan eugenol yang terdapat pada kayu manis menimbulkan aroma khas dan berbau wangi (Hastuti dan Rustanti, 2014). Sehingga panelis paling menyukai sampel ketiga dibandingkan dengan sampel pertama dan kedua karena aroma yang kurang kuat dibandingkan dengan sampel ketiga.

\section{Warna}

Warna merupakan sensori yang dapat dilihat langsung oleh panelis. Penentuan mutu bahan makanan umumnya bergantung pada warna yang dimilikinya, Warna yang menarik dan tampak alamiah dapat meningkatkan cita rasa (Negara et al., 2016). Berdasarkan uji hedonik dapat diketahui bahwa tingkat kesukaan panelis terhadap warna produk berbeda-beda. Sirup secang sampel kedua memiliki nilai skor kesukaan tertinggi, yaitu 3,41, sedangkan rasa yang 
paling tidak disukai adalah rasa sampel pertama dengan nilai kesukaan sebesar 3,29.

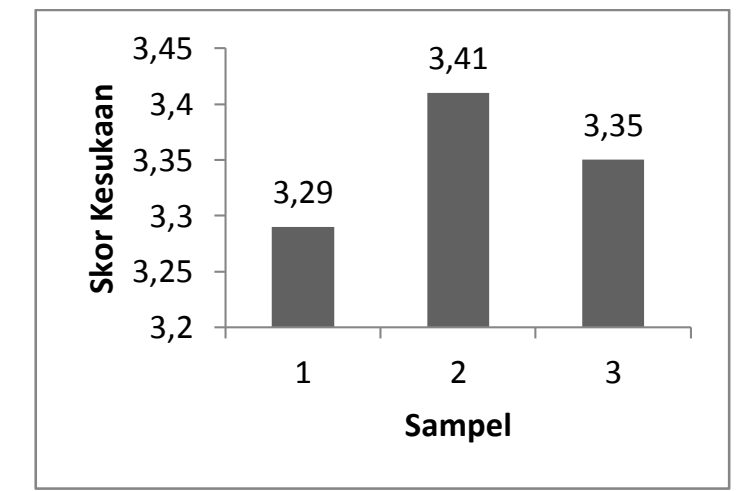

Gambar 4. Grafik rata - rata tingkat kesukaan warna sirup secang

Berdasarkan gambar 4 di atas, tingkat kesukaan warna menunjukkan sirup secang yang paling disukai adalah sirup secang dengan sampel kedua. Sampel kedua memiliki warna merah yang tidak terlalu pekat sehingga terlihat lebih menarik dibandingkan dengan sampel yang lain. Berdasarkan penilaian panelis pada sampel pertama dengan lama perebusan selama 60 menit warna merah yang dihasilkan merah terang dibandingkan dengan sampel kedua dan ketiga sedangkan sampel ketiga dengan lama perebusan selama 120 menit warna dihasilkan sedikit lebih pekat dibandingkan dengan sampel kedua. Proses perebusan akan menyebabkan terbentuknya warna kecoklatan akibat karamelisasi dari gula, perubahan tersebut tidak terlalu disukai oleh panelis (Jaya, Ginting, dan Ridwansyah, 2016).

\section{Kekentalan}

Tekstur makanan merupakan hasil dari respon indera peraba dan perasa terhadap bentuk rangsangan fisik ketika terjadi kontak antara bagian di dalam rongga mulut dan makanan. Tekstur makanan mencangkup kekentalan atau viskositas yang digunakan untuk cairan (Tarwendah, 2017).

Berdasarkan uji hedonik dapat diketahui bahwa tingkat kesukaan panelis terhadap kekentalan produk berbeda-beda. Sirup secang sampel kedua memiliki nilai skor kesukaan tertinggi, yaitu 3,15, sedangkan kekentalan yang paling tidak disukai adalah kekentalan sampel pertama dengan nilai kesukaan sebesar 2,95.

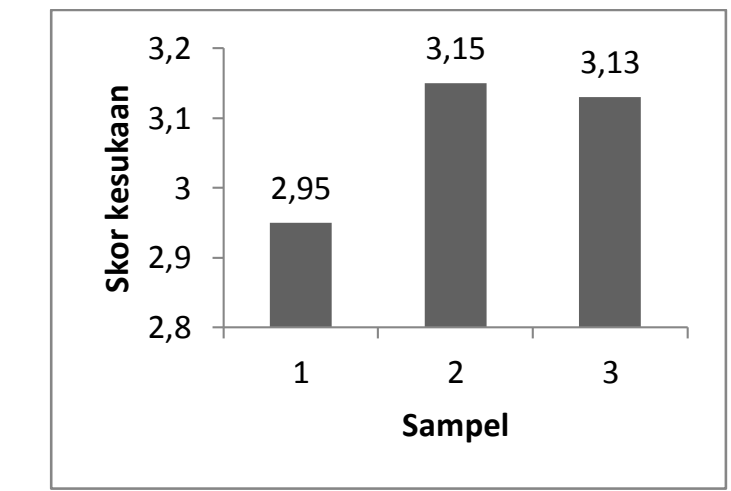

Gambar 5. Grafik rata - rata tingkat kesukaan kekentalan sirup secang

Berdasarkan gambar 5 di atas, tingkat kesukaan kekentalan menunjukkan sirup secang yang paling disukai adalah sirup secang dengan sampel 2. Berdasarkan penilaian panelis sampel pertama dengan lama perebusan 60 menit viskositas sirup masih kurang sedangkan sampel ketiga dengan lama perebusan 120 menit viskositas sirup lebih kental dibandingkan dengan sampel kedua. Lama pemanasan dapat mempengaruhi kekentalan atau viskositas, hal ini dikarenakan semakin lama proses pemanasan, suhu akan semakin meningkat dan hal tersebut dapat menyebabkan daya larut dari gula semakin tinggi. Air akan lebih banyak diikat oleh gula, sehingga viskositas meningkat (Susanto dan Setyohadi, 2011). Meskipun viskositas semakin meningkat seiring lama pemanasan namun panelis lebih menyukai sirup yang tidak terlalu cair maupun terlalu kental sehingga panelis lebih menyukai sirup secang sampel 2 dengan lama perebusan selama 90 menit.

\section{KESIMPULAN}

Berdasarkan hasil penelitian di atas dapat disimpulkan sebagai berikut: (1) Lama perebusan dapat menurunkan daya inhibisi sirup secang dari 56,644\% menjadi $28,803 \%$, $22,776 \%$ dan $29,593 \%$. (2) Lama perebusan akan mempengaruhi viskositas di mana semakin lama waktu perebusan viskositas 
semakin meningkat. (3) Tingkat kesukaan terhadap parameter rasa, aroma, warna dan kekentalan juga dipengaruhi oleh lama perebusan di mana panelis lebih menyukai sirup yang direbus selama 90 menit untuk parameter rasa, warna dan kekentalan sedangkan untuk aroma panelis menyukai sirup yang direbus selama 120 menit.

\section{SARAN}

Untuk penelitian selanjutnya perlu diberikan variasi konsentrasi ekstrak terhadap lama perebusan yang sudah dilakukan agar nilai aktivitas antioksidan $\left(\mathrm{IC}_{50}\right)$ dapat dihitung.

\section{DAFTAR PUSTAKA}

Aisyah, Y., Rasdiansyah, \& Muhaimin. (2015). Pengaruh pemanasan terhadap aktivitas antioksidan pada beberapa jenis sayuran. Jurnal Teknologi dan Industri Pertanian Indonesia, 6(2), 28-32. https://doi.org/10.17969/jtipi.v6i2.2063

Amperawati, S., Hastuti, P., Pranoto, Y., \& Santoso, U. (2019). Efektifitas frekuensi ekstraksi serta pengaruh suhu dan cahaya terhadap antosianin dan daya antioksidan ekstrak kelopak rosella (Hibiscus sabdariffa L.). Jurnal Aplikasi Teknologi Pangan, 8(1), 3845. https://doi.org/10.17728/jatp.3527

Ananda, R., Yuwono, S. S., \& Wijayanti, N. (2017). Pengaruh proporsi minyak dan lama pemanasan terhadap karakteristik fisiko kimia dan organoleptik bumbu betutu instan. Jurnal Pangan dan Agroindustri, 5(4), 49-57.

Bastanta, D., Karo-Karo, T., \& Rusmarilin, H. (2017). Pengaruh perbandingan sari sirsak dengan sari bit dan konsentrasi gula terhadap sirup sabit. J. Rekayasa Pangan dan Pertanian, 5(1), 102-108.

Dewi, S. R., Ulya, N., \& Argo, B. D. (2017). Kandungan flavonoid dan aktivitas antioksidan ekstrak Pleurotus ostreatus. Rona Teknik Pertanian, 10(2), 1-11.

Emilda. (2018). Efek senyawa bioaktif kayu manis (Cinnamomum burmanii nees) terhadap Diabetes melitus. Jurnal Fakultas Farmasi Umi, 5(1), 246-
252. https://doi.org/10.33096/jffi.v5i1. 316

Farhana, H., Maulana, I. T., \& Kodir, R. A. (2015). Perbandingan pengaruh suhu dan waktu perebusan terhadap kandungan brazilin pada kayu secang (Caesalpinia sappan Linn.). Prosiding Penelitian Spesia Unisba, 19-25.

Hendrik, G. W., Erwin, \& Panggabean, A. S. (2013). Pemanfaatan tumbuhan serai wangi (Cymbopogon nardus (L.) Rendle) sebagai antioksidan alami. Jurnal Kimia Mulawarman, 10(2), 7479. Retrieved from http://jurnal.kimia.fmipa.unmul.ac.id/in dex.php/JKM/article/view/34

Hastuti, A. M. \& Rustanti, N. (2014). Pengaruh penambahan kayu manis terhadap aktivitas antioksidan dan kadar gula total minuman fungsional secang dan daun stevia sebagai alternatif minuman bagi penderita diabetes melitus tipe 2. Journal of Nutrition College, 3(3), 362-369. https://doi.org/10.21776/ub.jtapro.2017 .018 .02 .3

Ishartani, D., \& Khasanah, L. U. (2012). Produksi bir pletok kaya antioksidan. Jurnal Teknologi Hasil Pertanian, 5(2), 32-39.

Jaya, R. S., Ginting, S., \& Ridwansyah. (2016). Pengaruh suhu pemanasan dan lama penyimpanan terhadap perubahan kualitas nira aren (Arenga pinnata). $J$. Rekayasa Pangan dan Pertanian, 4(1), 49-57.

Kusuma, M. S., Susilorini, T. E., \& Surjowardojo, P. (2017). Pengaruh lama dan suhu penyimpanan ekstrak daun sirih hijau (Piper betle linn) dengan aquades terhadap daya hambat bakteri Streptococcus agalactiae penyebab mastitis pada sapi perah. Ternak Tropika Journal of Tropical Animal Production, 18(2), 14-21. https://doi.org/10.21776/ub.jtapro.2017 .018 .02 .3

Lubis, N. A. (2018). Pengaruh kekentalan cairan terhadap waktu jatuh benda menggunakan falling ball method. Fistek: Jurnal Ilmu Fisika dan Teknologi, 2(2), 26-32. 
Mardhatilah, D. (2015). Pengaruh penambahan konsentrasi jahe dan rempah pada pembuatan sirup kopi. Agroteknose, 6(2), 55-61.

Miksusanti, Fitrya, \& Marfinda, N. (2011). Aktivitas campuran ekstrak kulit manggis (Garcinia mangstana L.) dan kayu secang (Caesalpina sappan L.) terhadap garcinia mangostana bacillus cereus. Jurnal Penelitian Sains, 14(3c), 41-47.

Mondo, F., Ansaharullah, \& Tamrin. (2017). Pengaruh penambahan ekstrak kayu secang (Caesalpinia sappan L.) terhadap lama penyimpanan susu kedelai. J. Sains dan Teknologi Pangan (JSTP), 2(2), 382-393.

Mursalim, M. F., \& Jamaluddin, A. W. (2019). Aktivitas antimikroba kombinasi ekstrak Propolis trigona $\mathrm{Sp}$ dan jahe (Zingiber officinale roscoe) terhadap bakteri salmonella thypimurium. AsSyifaa Jurnal Farmasi, 11(01), 70-74.

Badan Standarisasi Nasional Indonesia. (2013). SNI Sirup 3544:2013.

Negara, J. K., Sio, A. K., Rifkhan, Arifin, M., Oktaviana, A. Y., Wihansah, R. R. S., \& Yusuf, M. (2016). Aspek mikrobiologis serta sensori (rasa, warna, tekstur, aroma) pada dua bentuk penyajian keju yang berbeda. Jurnal Ilmu Produksi dan Teknologi Hasil Peternakan, 4(2), 286-290.

Nirmal, N. P., Rajput, M. S., Prasad, R. G. S. V., \& Ahmad, M. (2015). Brazilin from caesalpinia sappan heartwood and its pharmacological activities: a review. Asian Pacific Journal of Tropical Medicine, $\quad$ 8(6), 421-430. https://doi.org/10.1016/j.apjtm.2015.05 .014

Putri, U. S., Mukharomah, A. H., \& Sulistyaningsih, A. R. (2018). Pengaruh konsentrasi pelarut etanol terhadap absorbansi brazilin pada simplisia kayu secang (Caesalpinia sappan L.). Prosiding Seminar Nasional Mahasiswa Unimus, 1 . http://prosiding.unimus.ac.id/index.php /mahasiswa/article/view/50

Radhiansyah, M., Ansharullah, \& Khaeruni, A. (2018). Pengaruh konsentrasi kayu secang (Caesalpinia sappan L.) terhadap total mikroba, $\mathrm{PH}$ dan organoleptik daging ayam. J. Sains dan Teknologi Pangan, 3(3), 1314-1327.

Sayuti, N. A., \& Winarso, A. (2015). Stabilitas fisik dan mutu hedonik sirup dari bahan temulawak (Curcuma xanthorrhiza roxb.). Jurnal Ilmu Farmasi dan Farmasi Klinik, 11(1), 47-53.

Susanto, W. H., \& Setyohadi, B. R. (2011). Pengaruh varietas apel (Malus sylvestris) dan lama fermentasi oleh khamir saccharomyces cerivisiae sebagai perlakuan pra-pengolahan terhadap karakteristik sirup. Jurnal Teknologi Pangan, 12(3), 135-142.

Tarwendah, I. P. (2017). Jurnal review : studi komparasi atribut sensoris dan kesadaran merek produk pangan comparative study of sensory attributes and brand awareness in food product: a review. Jurnal Pangan dan Agroindustri, 5(2), 66-73.

Toegel, S., Wu, S. Q., Otero, M., Goldring, M. B., Leelapornpisid, P., Chiari, C., Kolb, A., Unger, F. M., Windhager, R., \& Viernstein, H. (2012). Caesalpinia Sappan extract inhibits ill $\beta$-mediated overexpression of matrix metalloproteinases in human chondrocytes. Genes And Nutrition, $7(2)$, 307-318. https://doi.org/10.1007/s12263-0110244-8

Towaha, J. (2012). Manfaat eugenol dalam berbagai industri di Indonesia. Jurnal Perspektif, 11(2), 79-90. http://dx.doi.org/10.1016/b978-0-12800097-7.00008-7 